\title{
Apoptotic cell-based therapies against transplant rejection: role of recipient's dendritic cells
}

\author{
Adrian E. Morelli • Adriana T. Larregina
}

Published online: 6 February 2010

(c) The Author(s) 2010. This article is published with open access at Springerlink.com

\begin{abstract}
One of the ultimate goals in transplantation is to develop novel therapeutic methods for induction of donorspecific tolerance to reduce the side effects caused by the generalized immunosuppression associated to the currently used pharmacologic regimens. Interaction or phagocytosis of cells in early apoptosis exerts potent anti-inflammatory and immunosuppressive effects on antigen (Ag)-presenting cells (APC) like dendritic cells (DC) and macrophages. This observation led to the idea that apoptotic cell-based therapies could be employed to deliver donor-Ag in combination with regulatory signals to recipient's APC as therapeutic approach to restrain the anti-donor response. This review describes the multiple mechanisms by which apoptotic cells down-modulate the immuno-stimulatory and pro-inflammatory functions of DC and macrophages, and the role of the interaction between apoptotic cells and APC in self-tolerance and in apoptotic cell-based therapies to prevent/treat allograft rejection and graft-versus-host disease in murine experimental systems and in humans. It also explores the role
\end{abstract}

A. E. Morelli $(\bowtie)$

T.E. Starzl Transplantation Institute, University of Pittsburgh Medical Center, E1546 Biomedical Science Tower, 200 Lothrop St., Pittsburgh, PA 15213-2582, USA

e-mail: morelli@imap.pitt.edu

\section{A. E. Morelli}

Department of Surgery, University of Pittsburgh Medical Center, Pittsburgh, PA 15213, USA

\section{A. E. Morelli · A. T. Larregina}

Department of Immunology, University of Pittsburgh Medical Center, Pittsburgh, PA 15213, USA

A. T. Larregina

Department of Dermatology, University of Pittsburgh Medical Center, Pittsburgh, PA 15213, USA that in vivo-generated apoptotic cells could have in the beneficial effects of extracorporeal photopheresis, donorspecific transfusion, and tolerogenic DC-based therapies in transplantation.

Keywords Transplantation · Tolerance - Apoptotic cells · Dendritic cells · Extracorporeal photopheresis

\section{Introduction}

Transplantation of organs, tissues or cells has become a common surgical procedure that frequently serves as the only life-saving treatment available for end-stage organ disorders. Allogeneic (allo) grafts are defined as organs/tissues/cells transplanted between totally or partially Major Histocompatibility (MHC) antigen (Ag)-mismatched individuals of the same species. According to the timing of onset, there are three main types of allograft rejection: hyperacute, acute and chronic. Hyperacute rejection takes place within minutes or hours after transplantation and is caused by deposition of pre-formed circulating antibodies $(\mathrm{Ab})$ on the endothelium of the graft vasculature and the consequent complement cascade activation. This type of rejection is in general preventable and rarely occurs. Acute rejection occurs within weeks or months after transplantation surgery, is caused by innate and adaptive immune responses, the latter mediated by donor-reactive $\mathrm{T}$ cells and anti-donor alloantibodies (alloAb), and is treatable by pharmacologic immuno-suppression. Chronic rejection takes place months or in general years after transplantation, is caused by immune and non-immune mechanisms, and does not respond to the currently employed immunosuppressive agents.

The development of nonspecific immunosuppressive agents and the better management of their therapeutic 
application and synergistic effects have decreased significantly the incidence of acute allograft rejection in the clinics. However, the currently used immunosuppressive drugs have shown little or no impact on chronic rejection and therefore on overall long-tern allograft survival. Importantly, long-term pharmacological immunosuppression is associated with toxicity and increased incidence of malignancies and infectious and metabolic diseases. Therefore, there is a need for the development of new donor-specific immunosuppressive therapies to control the mechanisms of allo-recognition that lead to graft rejection, and to reduce harmful side-effects of generalized immunosuppression. The finding that apoptotic cells exert potent anti-inflammatory and immunoregulatory effects on $\mathrm{Ag}$ presenting cells (APC) of the immune system has paved the way for the development of novel apoptotic cell-based therapies that have been used successfully in delaying transplant rejection and treating $\mathrm{T}$ cell-mediated autoimmune disorders in murine experimental models.

\section{Role of APC in initiation of allograft rejection}

One of the critical mechanisms of acute rejection is the $\mathrm{T}$ cell response mounted against donor MHC Ag. T cells recognize antigenic peptides presented by MHC molecules with the help of professional APC such as dendritic cells (DC), or amateur APC like monocyte, macrophages and B cells. Among professional APC, mature/activated DC are the most efficient at priming naïve $\mathrm{T}$ cells which exhibit a higher threshold of activation than memory $\mathrm{T}$ cells.

Transplanted organs are populated by immature $D C$ that are phagocytic with high capability for $\mathrm{Ag}$ internalization and processing, but that exhibit weak stimulatory capacity for naïve T cells due to the low levels of Ag-presenting and costimulatory molecules on the DC surface. Pro-inflammatory mediators released following transplant surgery and due to the effects of ischemia-reperfusion injury on the graft are sufficient to trigger the mechanisms of maturation/ activation of graft-resident and graft-infiltrating DC. These maturing DC migrate as passenger leukocytes out of the graft into secondary lymphoid tissues of the recipient, where they activate donor-specific naïve and memory $\mathrm{T}$ cells. However, besides their role in elicitation alloimmunity and as initiators of graft rejection, DC are critical to induce and maintain $\mathrm{T}$ cell peripheral tolerance, in particular following interaction with apoptotic cells.

\section{Immunoregulatory effects of apoptotic cells on APC}

It was originally assumed that the rapid clearance of apoptotic cells in vivo, before cell lysis and leakage of intracellular toxic mediators take place, was the reason by which phagocytosis of apoptotic cells by macrophages or immature DC does not elicit inflammatory or immune responses in steady-state conditions. Voll et al. [1] were the first to realize that apoptotic cells exert an active and potent immunosuppressive effect on monocytes, promoting secretion of interleukin (IL)-10 and decreasing release of the pro-inflammatory cytokines Tumor Necrosis Factor (TNF)- $\alpha$, IL-1 $\beta$ and IL-12. They also demonstrated that the immunoregulatory effect of apoptotic cells on APC is conserved between mammalian species and is independent of the apoptosis-inducing stimulus [1]. This profound down-regulatory effect of apoptotic cells on immunity occurs in professional and non-professional phagocytes and in non-phagocytic cells [2]. Accumulated evidence has shown that interaction and/or internalization of apoptotic cells by immature DC does not induce expression of the DC maturation-markers MHC class-II, CD40, CD80, CD86 and CD83 in vitro or in vivo, even after challenge with lipopolysaccharide (LPS), CD40-signaling, TNF- $\alpha$ or monocyte-conditioned medium [3-8]. By contrast, phagocytosis of cells undergoing primary necrosis or dying cells derived from virally-infected, activated or stressed cells promote DC maturation [3, 4, 9-11]. Besides the intrinsic characteristics of the dying cells, the pattern of opsonins deposited on the surface of apoptotic cells, the microenvironment where apoptotic cells die, and the efficiency of apoptotic cell clearance by phagocytes are critical factors that determine the outcome of the innate and adaptive immune responses [12].

It was initially assumed that, unlike early apoptotic cells which retain membrane integrity and exert immunosuppressive effects, late apoptotic cells (also known as secondarily necrotic cells) similarly to cells undergoing primary necrosis promote inflammation and immunity, since in both cases cells lose their membrane integrity and release potential pro-inflammatory mediators. However, Patel et al. [13] have shown in vitro that the mitogenactivated protein kinase (MAPK) signaling events triggered in macrophages by early apoptotic cells (inhibition of ERK1/2 and activation c-Jun N-terminal kinase and p38) are similar to those induced by late apoptotic cells and that, in both cases, were dominant over those triggered by necrotic cells. The inhibitory activity of late apoptotic cells on macrophages required the presence of the plasma membrane of the dying cells, and did not depend on soluble mediators released by the late apoptotic cells [13]. These results contradict the established paradigm that states that delayed clearance of apoptotic cells in vivo leads to accumulation of cells in late apoptosis that, by releasing pro-inflammatory mediators, promote auto-immunity. By contrast, they suggest that in those experimental models of autoimmunity associated to impaired clearance of 
apoptotic cells due to deficient expression of receptors or opsonins necessary for recognition of apoptotic cells, autoimmunity could be triggered, to some extent by the inability of the apoptotic cells to deliver inhibitory signals to APC, and not by the continuous release of pro-inflammatory mediators by non-internalized late apoptotic cells accumulated in the extracellular space [13].

DC that internalize cells in early apoptosis exhibit a selective decrease in the levels of mRNA and secretion of the pro-inflammatory cytokines IL- $1 \alpha$, IL- $1 \beta$, IL-6, IL-12p70 and TNF- $\alpha$, while secreting normal or increased amounts of immunosuppressive Transforming Growth Factor (TGF)- $\beta 1$ and IL-10, even in the presence of LPS [4, 14-16]. Phagocytosis of apoptotic neutrophils decreases DC secretion of IL-23, a cytokine involved in differentiation of Th17 lymphocytes and maintenance of Th1 memory [17]. The immunoregulatory effects are restricted to those DC that phagocytose apoptotic cells and not to bystander cells, indicating that the mechanism of DC inhibition involves cell-to-cell contact since it (1) requires recognition of ligands on the apoptotic cell surface through receptors expressed by the APC, and (2) is not caused by release of anti-inflammatory mediators into the extracellular milieu [6, 18]. Similarly, monocytes and macrophages exposed to apoptotic cells decrease secretion of IL- $1 \beta$, IL-12p70, IL-23 and TNF- $\alpha$, while maintaining or increasing the release of TGF- $\beta 1$, IL-10, and prostaglandin $\mathrm{E}_{2}[1,17$, 19-21]. Soluble mediators released by phagocytes during apoptotic cell clearance, not only prevent the inflammatory response, but also contribute to the resolution of inflammation and tissue restoration. During bacterial pneumonia in mice, alveolar macrophages that phagocytosed apoptotic neutrophils secrete Hepatocyte Growth Factor, a mediator that promotes proliferation of lung epithelial cells [22].

DC that acquire Ag from apoptotic cells present efficiently apoptotic cell-derived peptides to CD4 T cells and cross-present the internalized Ag to MHC class-I-restricted CD8 cytotoxic T cells [9, 23-25]. However, DC exposed to apoptotic cells decrease their ability to stimulate $\mathrm{T}$ cells, a phenomenon that seems to be related to the inhibitory effect of apoptotic cells on the amount of expression of MHC and co-stimulatory molecules, rather than to a defect in the Ag-processing function of the APC [3-6].

\section{How do apoptotic cells control the immunostimulatory function of APC?}

During the build up of the phagocytic synapse between the apoptotic cell and the phagocyte, a series of ApoptoticCell-Associated Molecular Patterns (ACAMP) present on the surface of apoptotic cells bind to Pattern-Recognition Receptors (PRR) expressed by the phagocytes. Membrane receptors like MerTK, TIM-1, -3 and -4 , the integrins $\alpha_{\mathrm{v}} \beta_{3}$ and $\alpha_{\mathrm{v}} \beta_{5}$, complement receptors (CR) 3 and 4, lectins, scavenger receptors (i.e. CD14, CD36, CD68, SR-A and LOX-1) and receptors for $\alpha_{2}$ macroglobulin (CD91), and $\beta_{2}$-glycoprotein I participate in apoptotic cell binding and/or ingestion by immature DC or macrophages [26-29]. In addition, a number of soluble proteins, including the complement fractions $\mathrm{C} 1 \mathrm{q}$ and $\mathrm{iC} 3 \mathrm{~b}$, milk fat globule protein-E8 (also known as lactadherin), growth arrestspecific gene-6 (GAS-6), protein S, collectins (i.e. mannose-binding lectin, surfactant proteins $A$ and D), pentraxins, thrombospondin-1, and serum $\beta_{2}$-glycoprotein I function as opsonins, forming molecular bridges between ligands on the membrane of apoptotic cells and PRR on the surface of the phagocytes [26-29].

Apoptotic cells down-regulate inflammation and the immunostimulatory function of APC via PRR-dependent and-independent mechanisms. The relative contribution of each PRR and the signaling pathways involved in the immunoregulatory effects of apoptotic cells on APC are beginning to be elucidated. Engagement of the thrombospondin receptor CD36 inhibited maturation and function of DC, that became unable to release IL-12 and secrete high levels of IL-10 in response to DC-activation stimuli [5]. Similarly, signaling via phosphatidylserine (PS) receptors using liposomes containing PS prevented maturation and reduced IL-12p70 secretion and T cell stimulatory function in human DC [30].

MerTK, a member of the Axl/Mer/Tyro3 receptor tyrosine kinase expressed by DC and macrophages, is a ligand for GAS-6, which binds to externalized PS on apoptotic cells [31-34]. Signaling of DC via MerTK by co-incubation with apoptotic cells activates the phosphatidylinositol 3-kinase (PI3K)/AKT pathway, which negatively regulates $\mathrm{NF}-\kappa \mathrm{B}$ activation and the consequent $\mathrm{DC}$ maturation [35]. Indeed, DC lacking MerTK expression or treated with PI3K inhibitors became refractory to the down-regulatory effect of apoptotic cells on LPS-induced secretion of TNF- $\alpha$ and IL-12p70 [35].

The surface of apoptotic cell binds the complement components $\mathrm{C} 1 \mathrm{q}$ and iC3b. Macrophages and DC interact with apoptotic cells via CR. Human monocyte-derived DC generated in the presence of $\mathrm{Clq}$ display impaired maturation, reduced secretion of IL-6, TNF- $\alpha$ and IL-12p70, and decreased $\mathrm{T}$ cell allo-stimulatory function following noncognate (LPS) or cognate (CD40-signaling) stimulation [36]. Interaction with iC3b-opsonized apoptotic cells prevented up-regulation of MHC class-II Ag, CD86, CC chemokine receptor (CCR)2, CCR5, and $\beta 2$ integrins, but increased expression of CCR7 in human DC [7]. Thus, DC that uptake of $\mathrm{iC} 3 \mathrm{~b}$-opsonized apoptotic cells in peripheral tissues remain immature/semi-mature, but capable of migrating in response to $\mathrm{CCR} 7$ ligands to secondary 
lymphoid organs and initiate or maintain $\mathrm{T}$ cell peripheral tolerance. Incubation of mouse and human immature DC with erythrocytes iC3b-opsonized or covered with $\mathrm{Ab}$ against the iC3b-binding domain of CR3 (CD11b/CD18), mimicked the down-regulatory effect of apoptotic cells on secretion of pro-inflammatory cytokines, without affecting release of TGF- $\beta 1[14,37]$. Human DC exposed to surrogate apoptotic cells capable of signaling exclusively through CR3, processed and presented normally exogenous $\mathrm{Ag}$, but became impaired to prime efficiently naïve $\mathrm{T}$ cells into effector cells [37]. By contrast, Behrens et al. [38] have shown that the absence of $\mathrm{iC} 3 \mathrm{~b}$ in serum does not alter the immunoregulatory effects of apoptotic cells on DC in vitro, a phenomenon likely due to redundancy in the apoptotic cell receptor system.

Apoptotic cells also modulate the function of DC through more indirect mechanisms. Co-culture of DC with apoptotic cells promoted secretion of interferon (IFN)- $\gamma$ that up-regulated via autocrine and paracrine loops the DC content of the active form of indoleamine 2,3-dioxygenase, an enzyme that degrades the essential amino acid tryptophan into metabolites that inhibit $\mathrm{T}$ cell function [15]. DC exposed to apoptotic cells released large amounts of nitric oxide that impairs the $\mathrm{T}$ cell response [16].

Some of the inhibitory effects of apoptotic cells on APC take place at the mRNA transcription level. In macrophages, signals derived from the contact with apoptotic cells, likely via interaction of externalized PS with its receptors, reduced the level of tyrosine phosphorylation of the transcription repressor factor GC-BP, enhancing its ability to bind the IL-12p35 promoter and selectively repressing transcription of the IL-12p35 gene [21].

Besides their potent immunoregulatory effects mediated indirectly through phagocytes, apoptotic cells by themselves down-modulate inflammation and immunity. $\mathrm{T}$ cells undergoing apoptosis released IL-10 and the latent and active forms of TGF- $\beta$ into the extracellular milieu [39, 40]. In T lymphocytes, programmed cell death promoted synthesis of IL-10, whereas TGF- $\beta$ secretion resulted from release of existing cytokine pools stored in intracellular membrane-bound compartments like mitochondria [39, 40]. In addition, apoptosis triggered de novo synthesis and release of thrombospondin 1 in monocytes and neutrophils, a protein that binds avidly to immature DC enhancing engulfing of apoptotic cells and preventing DC maturation in response to LPS stimulation [41]. Ariel et al. [42] have shown that the chemokine receptor CCR5 is mobilized to the cell surface of neutrophils and $\mathrm{T}$ cells undergoing apoptosis. CCR5 expressed on the surface of apoptotic leukocytes remained functional and sequestered efficiently its ligands CCL3 and CCL5 from sites of inflammation, constituting a mechanism of resolution of the inflammatory response [42]. The mechanisms by which early apoptotic cells down-regulate inflammation and the function of DC are summarized in Fig. 1.

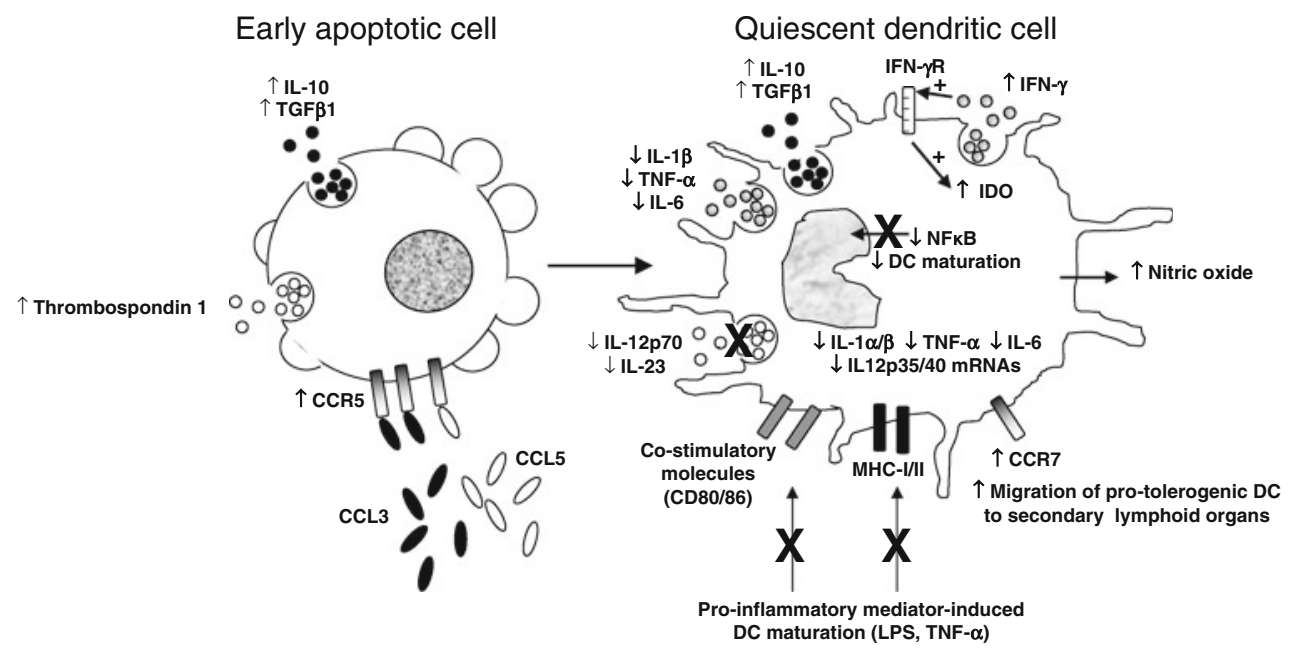

Fig. 1 Anti-inflammatory and immunosuppressive mechanisms of apoptotic cells. Leukocytes undergoing apoptosis release the immunosuppressive cytokines IL-10 and TGF- $\beta 1$, and soluble thrombospondin 1 which functions as a bridge between apoptotic cells and phagocytic APC and down-regulates the immunostimulatory function of DC. Apoptotic leukocytes increase surface expression of CCR5 that sequesters the inflammatory chemokines CCL3 and CCL5, facilitating the resolution of inflammation. Following interaction or phagocytosis of apoptotic cells, DC (i) become resistant to maturation/activation in response to pro-inflammatory stimuli; (ii) increase IL-10 and TGF- $\beta 1$ secretion, release nitric oxide, and augment their intracellular content of functional indoleamine 2,3-dioxygenase (IDO); and (iii) up-regulate CCR7 expression, which allows peripheral tissue-resident DC that engulfed apoptotic cells to migrate to secondary lymphoid organs. Some of the immunosuppressive effects of apoptotic cells on APC occur at the level of mRNA transcription or processing 
Apoptotic cells and maintenance of $\mathbf{T}$ cell peripheral tolerance

Self-reactive $\mathrm{T}$ cells that escape central (thymic) deletion migrate to secondary lymphoid organs. Therefore, an efficient mechanism of peripheral tolerance must monitor and de-activate, delete or regulate auto-reactive $\mathrm{T}$ cell clones in periphery to prevent autoimmunity [43, 44]. Elegant experiments in mice expressing transgenic Ag controlled by tissue-specific promoters have shown that, in normal conditions, constitutive migration of APC from peripheral tissues to draining lymphoid organs, results in presentation of tissue-derived Ag to T cells [45, 46]. However, migration of peripheral APC carrying the transgenic self-Ag acquired from neighboring parenchymal cells resulted in suppression of Ag-specific CD4 and CD8 T cells [45, 46]. These findings, together with results obtained from experiments of in situ-targeting of DC in vivo [47, 48], led to the hypothesis that during induction/maintenance of peripheral $\mathrm{T}$ cell tolerance, semi-mature DC mobilized from peripheral tissues or resident in secondary lymphoid organs, present self-Ag in a pro-tolerogenic fashion to down-regulate those auto-reactive $\mathrm{T}$ cell clones that escaped thymic deletion [43].

Every day, billions of tissue cells die by apoptosis as part of the physiologic mechanism of cell turn-over. These apoptotic cells constitute an excellent source of self-Ag for immature DC in periphery. DC with engulfed apoptotic bodies or cellular fragments derived from neighboring parenchymal cells have been reported within or in the vicinity of epidermis, and intestine, gastric or vaginal epithelia [49-52]. Importantly, although interaction or engulfment of apoptotic cells prevents DC activation/ maturation, it does not affect the ability of immature/semimature DC to migrate to secondary lymphoid organs. DC that engulf apoptotic cells, although remain immature, increase their surface expression of CCR7, a chemokine receptor required for peripheral DC to migrate to secondary lymphoid organs in response to the chemokines CCL19 and CCL21 [7, 53]. Indeed, DC with internalized apoptotic cell fragments derived from intestinal epithelial cells and gastric parietal cells have been detected in Peyer's patches and mesenteric lymph nodes, and in stomach-draining lymph nodes, respectively $[50,51]$.

The presence of DC with internalized apoptotic cells in secondary lymphoid organs is not always due to migration of peripheral DC. In mice, spleen-resident CD11 $\mathrm{c}^{\mathrm{hi}} \mathrm{CD} 8^{-}$ or $\mathrm{CD} 8 \alpha^{+} \mathrm{DC}$, unlike CD11 $\mathrm{c}^{\text {int }}$ plasmacytoid DC, capture efficiently blood-borne apoptotic leukocytes [18]. Similarly, in humans, it has been shown that myeloid DC, unlike plasmacytoid DC, internalize apoptotic cells [54].

Experiments of adoptive transference of TCR transgenic $\mathrm{T}$ cells in mice have shown that both types of conventional
CD11c ${ }^{\text {hi }}$ DC (tissue-migratory and secondary lymphoid organ-resident) are capable of presenting apoptotic cellderived peptides to T cells [51]. In vivo, under steady-state conditions, presentation by splenic DC of apoptotic cellderived peptides loaded in MHC class-I or -II molecule leads to clonal deletion of Ag-specific CD8 or CD4 T cells, respectively, and generation of Ag-specific regulatory $\mathrm{T}$ cells (Treg) [55-58]. Recent evidence indicates that apoptotic cells may exert immunosuppressive effects via generation of $\mathrm{CD} 19^{+}$regulatory $\mathrm{B}$ cells, which influence the function of effector T cells [59].

Together, the accumulated evidence indicates that internalization of endogenous apoptotic cells by immature/semimature APC, through an extremely efficient mechanism of apoptotic cell clearance, is followed by deletion and/or regulation of self-reactive lymphocytes and therefore, prevention of autoimmunity. Indeed, mice with deficiencies in molecules critical for recognition, internalization, or lysosomal DNA degradation of apoptotic cells, including C1q, C4, IgM, the pentraxin Serum Amyloid P, MerTK, milk fat globule protein-E8, class A scavenger receptors, or lysosomal DNase II develop systemic autoimmune disorders [60-68]. In humans, systemic lupus erythematosus is associated with genetic deficiencies in complement factors $[69,70]$, and with defective phagocytosis of apoptotic cells $[71,72]$.

\section{Apoptotic cells as therapeutic tools in transplantation}

The concept that processing of endogenous apoptotic cells by quiescent APC in secondary lymphoid organs is necessary for induction and/or maintenance of peripheral self-tolerance in the steady-state [73], led to the idea that systemic (i.v.) administration of donor leukocytes undergoing apoptosis could be used to deliver in situ the entire repertoire of donor allo-Ag together with immunoregulatory signals to recipient's APC, to induce donor-specific immunosuppression in transplantation [reviewed in 74-76]. Since internalization of apoptotic cells prevents APC maturation/ activation, presentation of apoptotic cell-derived allo-peptides by recipient's quiescent APC expressing a low ratio of $\mathrm{T}$ cell co-stimulatory versus co-regulatory molecules, could be employed therapeutically to promote deletion, anergy and/or regulation of donor-reactive $\mathrm{T}$ cells and therefore, to prolong allograft survival.

\section{Apoptotic cell therapies restrain allo-immunity and acute rejection in cardiac transplantation}

Therapies based on administration of donor-derived apoptotic leukocytes have been proven to exert beneficial 
effects in murine models of cardiac transplantation. I.v. administration of a single dose of donor splenocytes in early apoptosis, 7 days before transplantation, prolonged significantly survival of heterotopic (abdomen) vascularized cardiac allografts in mice and rats [57, 77]. The beneficial effect of apoptotic cells was donor-specific, took place in different donor and recipient strain combinations, and depended on the biological properties of the apoptotic cells, since i.v. injection of donor splenocytes undergoing primary necrosis (induced by freezing-thawing) did not affect graft survival [57, 77]. Prolongation of cardiac allograft survival was independent on the method employed to induce apoptosis, as similar results were obtained with apoptotic cells generated by UV-B- or $\gamma$-irradiation [77]. However, the therapeutic effect depended critically on the timing of administration of apoptotic cells, with optimal results achieved when donor apoptotic splenocytes were injected 7 days prior to transplantation [77].

Trafficking studies have demonstrated that allogeneic apoptotic splenocytes injected i.v. are internalized within a few hours by red pulp macrophages and by specialized phagocytes and DC of the marginal zone of the spleen [14, $18,57,78]$. In mice, splenic CD11c ${ }^{\text {hi }}$ DC (mainly the $\mathrm{CD} 8 \alpha^{+}$DC of the marginal zone), unlike the CD $11 c^{\text {int }}$ plasmacytoid DC, internalized in vivo early apoptotic cells administered i.v. [18, 79]. At later time points, these marginal zone DC containing phagocytosed apoptotic cell fragments migrated to the $\mathrm{T}$ cell areas of the splenic follicles for cross-presentation of the apoptotic cell-derived Ag [14, 79].

Since phagocytosis of apoptotic cells prevents APC maturation in vivo, DC that internalize and process donor apoptotic cells present apoptotic cell-derived allopeptides to donor-reactive $\mathrm{T}$ cells in the context of low co-stimulation [57]. This sequence of events leads to deficient activation, followed by transient proliferation and deletion of donor-reactive $\mathrm{T}$ cells, as demonstrated in vivo by injecting systemically allogeneic apoptotic splenocytes into host mice previously reconstituted with allo-reactive TCR transgenic CD4 T cells [57]. In this model, presentation of donor apoptotic cell-derived allopeptides by immature/ semi-mature DC in the spleen promoted transient proliferation of anti-donor CD4 $\mathrm{T}$ cells unequipped for homeostatic survival. These unfitted CD4 T cells expressed lower levels of the anti-apoptotic protein $\mathrm{Bcl}-\mathrm{X}_{\mathrm{L}}$ and the cytokine receptors IL-7R $\alpha$ (CD127), IL-15R $\alpha$ and the common cytokine receptor gamma chain $\left(\gamma_{c}\right.$ or CD132), than control $\mathrm{T}$ cells fully activated [57]. I.v. injection of $\mathrm{BALB} / \mathrm{c}$ apoptotic splenocytes into C57BL/6 J hosts adoptively transferred with $1 \mathrm{H} 3.1$ TCR transgenic CD4 T cells (specific for the BALB/c IE $\alpha_{52-68}$ peptide presented by $\mathrm{C} 57 \mathrm{BL} /$ $6 \mathrm{~J} \mathrm{IA}^{\mathrm{b}}$ MHC class-II molecules) was associated 14 days later, with (1) increased percentage of splenic $1 \mathrm{H} 3.1 \mathrm{~T}$ cells expressing the Treg marker FoxP3 and (2) increased IL-10 and reduced IFN- $\gamma$ secretion of splenocytes in response to ex vivo re-stimulation with the $\mathrm{BALB} / \mathrm{c}$ (donor) $\mathrm{IE} \alpha_{52-68}$ peptide [18]. Similarly, donor apoptotic cell therapy decreased drastically cross-priming of donor-reactive $2 \mathrm{C}$ TCR transgenic CD8 $\mathrm{T}$ cells in vivo in the same mouse model [18]. These results explain why, 7 days post-transplant, recipient mice and rats pre-treated with donor apoptotic cells reduced drastically the systemic anti-donor type $1 \mathrm{~T}$ cell response, and exhibited minimal parenchymal damage and decreased leukocyte infiltration in the allografts, compared to untreated controls [57, 77].

It is likely that, for clinical application in transplantation, apoptotic cell therapies will be administered in combination with reduced levels of pharmacological immunosuppression, to enhance the beneficial effects of apoptotic cells and minimize the side-effects caused by the immunosuppressive regimen. In this regard, infusion of donor apoptotic splenocytes, plus a single suboptimal dose of anti-CD40 ligand blocking Ab (to prevent the stimulatoy effect of CD40-signaling on recipient's APC) prolonged indefinitely ( $>100$ days) survival of cardiac allografts in mice [57]. Interestingly, the long-term allografts showed minimal tissue damage and were infiltrated by small foci of leukocytes composed mainly of $\mathrm{CD} 4^{+} \mathrm{FoxP}^{+} \mathrm{T}$ cells with intracellular content of IL-10 and TGF- $\beta 1$ [57]. The fact that transference of splenic $\mathrm{T}$ cells from long-term C57BL/ $10 \mathrm{~J}$ recipients pre-treated with donor apoptotic splenocytes, into naïve (untreated) C57BL/10J mice prolonged significantly survival of cardiac allografts from the same donor, but not third-party grafts, indicates that in that model donor apoptotic cell therapy promoted generation/expansion of donor-specific Treg [57].

Donor apoptotic splenocytes have also been used indirectly in combination with tolerogenic DC therapies. Intraportal administration, 7 days prior to transplantation, of recipient's bone marrow-derived maturation-resistant DC loaded in vitro with donor apoptotic splenocytes prolonged significantly survival of heart allografts in otherwise nonimmunosuppressed mice [80].

\section{Recipient's APC mediate immunoregulatory effects of apoptotic cell therapies in cardiac transplantation}

There is evidence that the effect of apoptotic cell therapy on cardiac allograft survival is mediated, at least in part, through recipient's APC. Adoptive transference of freshlyisolated splenic $\mathrm{CD} 11 \mathrm{c}^{+} \mathrm{DC}$ of $\mathrm{C} 57 \mathrm{BL} / 10 \mathrm{~J}$ mice, pretreated (i.v., 24-36 h earlier) with BALB/c apoptotic splenocytes, into naïve C57BL/10J, prolonged significantly survival of BALB/c hearts transplanted 7 days later [57]. 
This effect required the presence of the subset of $\mathrm{CD} 8 \alpha^{+}$ DC in the transferred inoculum [57], and agrees with similar findings reported in a mouse model of adoptive transfer of inhibition of contact hypersensitivity induced by i.v. injected haptenated apoptotic cells [56].

In a cardiac transplantation model in mice, transient depletion of CD11 $\mathrm{c}^{\text {hi }}$ DC without affecting the subset of CD11 $c^{\text {int }}$ plasmacytoid DC, at the time of i.v. administration of allogeneic apoptotic splenocytes was followed by lack of proliferation of allo-reactive TCR transgenic CD4 T cells in the spleen [18]. Together, these results suggest that the beneficial effect of donor apoptotic cell therapies on cardiac allograft survival are mediated by recipient's $\mathrm{CD} 11 \mathrm{c}^{\text {hi }}$ DC (likely the CD $8 \alpha^{+}$DC subset in mice) resident in secondary lymphoid organs. In this model, splenic $\mathrm{CD} 11 \mathrm{c}^{\mathrm{hi}} \mathrm{DC}$ that capture donor apoptotic splenocytes from circulation remained quiescent in vivo and resistant to maturation in response to DC-activating stimuli [18]. However, their ability to present allo-peptides from bloodborne apoptotic cells is short-lived, reaching a plateau 3 days after apoptotic cell i.v. administration [18]. Presentation of donor apoptotic cell peptides by recipient's quiescent DC was critical for prolongation of cardiac allograft survival, since the effect was abrogated by induction of DC maturation in situ through CD40-signaling [57].

Sun et al. [77] have shown that blockade of phagocytosis with gadolinium chloride, before i.v. injection of apoptotic splenocytes, abrogates their therapeutic effect on cardiac allograft survival in rats. This finding indicates that immature DC and/or macrophages via (1) phagocytosis, processing and presentation of apoptotic cell-derived allo-Ag, and/or (2) secretion of anti-inflammatory/immuno-suppressive mediators, are critical for the immunoregulatory effects of exogenous apoptotic cells in cardiac transplantation. Indeed, the same group [77] demonstrated indirectly that donor apoptotic splenocytes infused i.v. exert their immunoregulatory effects by interacting with PRR expressed by recipient's APC. In this study, blockade of externalized PS by incubation with soluble annexin- $\mathrm{V}$ reduced drastically the ability of donor apoptotic splenocytes to prolong heart allograft survival in rats, compared to controls injected with untreated apoptotic cells [77].

In other transplantation models, recipient's macrophages, instead of DC, seem to mediate the therapeutic effect of apoptotic cells. Transient deletion of CD11 $\mathrm{c}^{\text {hi }}$ DC in transgenic mice encoding for the diphtheria toxin receptor driven by the $\mathrm{CD} 11 \mathrm{c}$ promoter, did not affect the graft-facilitating effect of apoptotic cells on bone marrow transplantation [78]. By contrast, depletion of host's macrophages by infusion of clodronate-loaded liposomes reduced significantly apoptotic cell-induced donor bone marrow engraftment [78]. In a mouse model of induced experimental autoimmune encephalomyelitis, in which i.v. administration of apoptotic cells containing the self- $\mathrm{Ag}$ myelin olygodendrocyte glycoprotein prevented autoimmunity, splenic marginal zone macrophages were critical for the beneficial effect of the injected apoptotic cells [81]. These macrophages controlled the clearance of the exogenous apoptotic cells and their selective engulfment by splenic $\mathrm{CD} 8 \alpha^{+} \mathrm{DC}$, which were likely the final responsible cells for the tolerogenic effect [81].

\section{Apoptotic cell therapies in chronic rejection}

Chronic rejection of solid allografts, in particular kidney, heart and lung, is a major problem that prevents long-term graft survival in an elevated percentage of recipients. Importantly, currently employed immunosuppressive regimens fail to prevent chronic rejection. One of the key pathological features of chronic rejection is the presence, in medium and small size arteries of the graft, of chronic allograft vasculopathy (CAV). Vessels affected by CAV develop endothelialitis, intimal thickening, elastic fiber disruption, adventitial fibrosis and leukocyte infiltration, which together lead to progressive reduction of the vascular lumen and its obstruction by thrombosis. CAV is caused by non-immune and by innate and adaptive immune mechanisms, the latter ones through donor-reactive $\mathrm{T}$ cells and alloAb.

The adaptive immune response that in part causes chronic rejection is elicited via the indirect pathway of allorecognition, a mechanism by which donor-reactive $\mathrm{T}$ cells recognize donor allo-peptides presented by self (recipient's)-MHC molecules. Indirect pathway T cells are also critical to provide help to donor-reactive B cells, which then differentiate into the plasma cells that secrete alloAb. Since i.v. injected donor apoptotic cells are processed by recipient's APC for presentation to indirect pathway $\mathrm{T}$ cells, apoptotic cell therapies can be used as a therapeutic approach to (1) down-regulate the indirect pathway $\mathrm{T}$ cell response; (2) reduce the level of cognate interaction and cooperation between indirect pathway $\mathrm{T}$ cells and allo-reactive B cells, which is critical for generation of alloAb; and (3) prevent, delay or ameliorate signs of chronic rejection.

In mice, administration of donor apoptotic splenocytes 7 days prior to transplant, minimized substantially the histopathological features of CAV in fully-mismatched aortic allografts, an established experimental model of CAV [18]. The effect was donor- and apoptotic cell-specific, since third-party apoptotic cells, or donor splenocytes alive or undergoing primary necrosis (induced by freezingthawing) did not prevent development of CAV in the same model. Sixty days after transplant, those recipients that 
received donor apoptotic splenocytes exhibited a drastic decrease in: (1) the number of indirect pathway (polyclonal) $\mathrm{T}$ cells secreting IFN- $\gamma$ and (2) the amount of circulating alloAb, compared to controls [18].

Nouri-Shirazi and Guinet [82] have shown in vitro that human immature DC incubated with allogeneic apoptotic cells promote allo-specific CD4 $\mathrm{T}$ cell anergy via the indirect pathway. This finding suggests that systemic administration of donor apoptotic cells or alternatively, immature DC loaded with donor apoptotic cells, could restrain the indirect $\mathrm{T}$ cell response during the chronic phase of organ transplantation in humans.

\section{Apoptotic cell therapies in bone marrow transplantation}

The therapeutic potential of allogeneic bone-marrow or hematopoietic stem cell transplantation for treatment of malignant and genetic hematologic disorders has been limited by immunologic complications. The presence of remaining functional donor-reactive $\mathrm{T}$ cells and NK cells, resistant to the conditioning regimen in the recipient, triggers allograft rejection and prevents engraftment of donor bone marrow cells. On the donor's side, T cells that recognize recipient's MHC $\mathrm{Ag}$ and adoptively transferred with the bone marrow allograft are the cause of graft-versus-host-disease (GvHD). Apoptotic cell therapies have been used to facilitate bone marrow cell engraftment and prevent GvHD.

In a restrictive model of bone marrow transplantation in mice, co-administration of apoptotic cells (i.v.) the day of the transplant enhanced bone marrow engraftment and prevented GvHD in different donor-recipient strain combinations [83]. Prevention of GvHD was associated to the in vivo expansion of donor-derived $\mathrm{CD} 4^{+} \mathrm{CD} 25^{+}$Treg, which somehow restrained the anti-recipient response to peripheral tissues that leads to GvHD [78]. The therapeutic effect of apoptotic cells was independent of the stimulus employed to trigger cell death, and interestingly, was unspecific since it occurred following administration of third-party or xenogeneic (human) apoptotic leukocytes [83]. However, this apparent lack of allo-specificity could be due to the fact that the bone marrow allograft and the bolus of apoptotic cells were administered simultaneously, providing recipient's APC with donor Ag and at the same time with bystander immunoregulatory signals supplied by the injected apoptotic cells regardless their origin. Importantly, in this model, addition of apoptotic cells to the bone marrow allografts also reduced Ab-mediated anti-donor responses [84], and increased the percentage of donorderived $\mathrm{CD} 4 \mathrm{~T}$ cells with phenotype $\left(\mathrm{CD} 25^{+} \mathrm{FoxP}^{+}\right.$ CD62L ${ }^{\text {hi }}$ CTLA- $4^{\text {hi }}$ ) and function of Treg [78]. The ability of apoptotic cell therapy to promote bone marrow engraftment, down-regulate alloAb secretion, and augment the percentage of Treg was mediated through TGF- $\beta$ released likely by phagocytes during their interaction with the injected apoptotic cells and/or directly by the apoptotic cells [78].

\section{Role of apoptotic cells in extracorporeal photopheresis in transplantation}

Extracorporeal photopheresis (ECP) is a technique in which a fraction of the patient's peripheral blood is transiently removed and separated by leukapheresis into leukocytedepleted blood and leukocyte-enriched plasma. The former is returned into the patient without further treatment, whereas the mononuclear cell-enriched fraction is incubated ex vivo with the photosensitizing drug 8-methoxypsoralen and exposed to UV-A radiation $(350 \mathrm{~nm})$, and then reinfused in a close-loop, patient-connected system. In the presence of UV-A light, 8-methoxypsoralen covalently binds to DNA pyrimidine bases, cell-surface and cytoplasmic molecules, priming the target leukocytes for apoptosis. The ability of ECP to down-regulate the $\mathrm{T}$ cell response in vivo has been demonstrated in auto-, allo- and xenoimmunity [85-87]. In humans, addition of ECP to conventional pharmacologic immunosuppression decreased the risk of acute rejection in recipients of cardiac allografts [88] and was effective for treatment of ongoing episodes of acute heart rejection during the first year after transplantation [89, 90]. ECP has been also tested with success in patients with kidney, lung, liver or face allograft rejection [91-95], or GvHD [96, 97], in particular in cases refractory to conventional pharmacologic immunosuppression.

Despite the promising results in the clinics, the mechanism(s) by which ECP down-regulates the immune response in vivo remains unclear. The beneficial effect of ECP in transplantation can not be attributed simply to the induction of apoptosis in donor-reactive lymphocytes, since less than $10 \%$ of the peripheral leukocytes are exposed ex vivo to 8-methoxypsoralen and UV-A radiation. Interestingly, patients treated for long-term with ECP do not exhibit higher incidence of infections or malignancies [98] and respond normally to novel and recall $\mathrm{Ag}$ [99], suggesting that treatment with ECP does not cause generalized immunosuppression. These observations have led to the conclusion that the therapeutic effects of ECP are mediated via systemic Ag-specific immunoregulation.

Among the cells irradiated during ECP, circulating lymphocytes, monocytes and DC are sensitive to apoptosis [100-105], generating apoptotic bodies and blebs with immunoregulatory properties [106]. Even before dying, human DC treated with 8-methoxypsoralen and UVA, 
promote Th2-biased responses and decrease drastically their ability to drive Th1 polarization [107, 108]. Once reinfused, the ECP-treated leukocytes are retained primarily in the spleen and liver $[100,101]$, likely by internalization by tissue-resident macrophages and immature DC, as shown for UV-B-irradiated splenocytes injected i.v. [14]. In humans, immature DC internalized efficiently ECP-treated leukocytes [104], and incubation with ECPtreated leukocytes increased IL-10 secretion and prevented up-regulation of co-stimulatory molecules in DC, and augmented the IL-10 and IL-1R antagonist mRNA content in peripheral leukocytes, even in presence of LPS [102, 109]. In one study, ECP-treated leukocytes increased their release of HLA-G molecules which play an important role in down-regulation of $\mathrm{T}$ cell immunity [103]. Together, these findings suggest that the reinfused ECP-treated leukocytes enhance the pro-tolerogenic function of those quiescent DC (and likely macrophages) that interact with them. In this regard, transference of ECP-treated splenocytes from mice sensitized with dinitrofluorobenzene into naïve mice caused inhibition of contact hypersensitivity in a hapten-specific way, and the inhibition was lost when the transferred splenocytes were depleted of $\mathrm{CD} 4^{+}$or $\mathrm{CD} 25^{+}$ lymphocytes $[100,101]$. This latter finding suggests that ECP exerts immunoregulatory effects, at least partly, via Ag-specific Treg.

There is evidence that the regulatory effect of ECP on allo-immunity is also mediated, to some extent, through of allo-specific Treg. Transference of splenic $\mathrm{CD} 4{ }^{+} \mathrm{CD} 25^{+} \mathrm{T}$ cells from ECP-treated mice transplanted with fully-mismatched hearts, prolonged survival of cardiac allografts from the same donor strain in naïve recipients [110]. In vivo depletion of Treg prevented the beneficial effect of ECP in a mouse model of GvHD [111]. In humans, recipients of heart, lung, or kidney allografts or with GvHD treated with ECP in addition to conventional immunosuppression, exhibited a higher frequency of peripheral $\mathrm{T}$ cells with Treg phenotype $\left(\mathrm{CD} 4^{+} \mathrm{CD} 25^{+} \mathrm{FoxP}^{+} \mathrm{CD}^{-} 9^{-}\right)$and function [104, 112-114]. Treatment with ECP also augments the regulatory function of peripheral $\mathrm{CD} 4^{+} \mathrm{CD} 25^{+}$ $\mathrm{FoxP}^{+}$Treg by increasing their CD39-mediated production of adenosine, a soluble immunosuppressive mediator of $T$ cell activation [115]. Further studies will reveal the specificity of the $\mathrm{CD} 4^{+}$Treg generated following ECP.

\section{Role of apoptotic cells in living cell-therapies and Ab-based immunosuppression in transplantation}

In recent years, there has been increasing evidence that the beneficial effects achieved with living cell-based therapies (i.e. blood transfusion, tolerogenic DC administered systemically), or anti-CD3 Ab-induced immunosuppression are mediated through generation of apoptotic cells in vivo (Fig. 2).

One of the first cell-based therapies employed to restrain the anti-donor response and prolong solid allograft survival consisted in administration of randomly selected, haplotype-shared or donor-specific transfusions (DST), in most cases in combination with pharmacological immunosuppression [116-121]. It was initially assumed that the immunosuppressive effect of DST was mediated through direct interaction of the transfused leukocytes expressing donor $\mathrm{MHC} \mathrm{Ag}$ with anti-donor $\mathrm{T}$ cells in secondary lymphoid organs [reviewed in 122]. However, different laboratories [123-125] have independently shown that the DST effect requires presentation of donor allopeptides in the context of recipient's MHC molecules to anti-donor $\mathrm{T}$ cells via the indirect pathway. Importantly, once injected i.v., non-self leukocytes have a limited life-span since they become targets of recipient's NK cells. These finding suggest that, as soon as the transfused leukocytes become apoptotic in vivo, they are internalized by recipient's quiescent APC, which then present the apoptotic cell-derived donor allopeptides to indirect pathway $\mathrm{T}$ cells. Since the transfused leukocytes are likely engulfed by phagocytic APC as soon as they show early signs of apoptosis, it is expected that internalization of apoptotic cells will deliver a potent immunoregulatory signal plus donor $\mathrm{Ag}$ to recipient's APC, leading to down-modulation of the anti-donor response.

The use of DST as clinical therapy was discontinued in the early 80 s due to the risk of sensitization and the advent of new immunosuppressive agents. More recently, tolerogenic DC-based therapies based on i.v. administration of in vitro-generated donor or recipient-derived DC have been used with relative success to delay or prevent solid allograft rejection or GvHD in murine models [reviewed in 126]. In tolerogenic DC-based therapies, immature, maturation-resistant, or alternatively-activated DC are generated in vitro by different culture, pharmacologic or genetic methods and then administered i.v. into graft recipients, with optimal results in murine models when the DC are administered 7 days prior to transplantation.

As originally assumed for the DST effect, the general idea is that the injected DC interact directly with anti-donor $\mathrm{T}$ cells in vivo, leading to anergy, deletion and/or regulation. To our knowledge this concept has never been tested in vivo, since all studies have examined the capacity of the therapeutic DC to down-modulate the anti-donor $\mathrm{T}$ cell response in vitro, or in ex vivo assays after transplantation. Another possibility is that, as demonstrated in DST, recipient's APC present donor alloAg acquired from the therapeutic DC injected i.v.. In agreement with that idea, in certain mouse strain combinations, repetitive i.v. injection of UV-B irradiated allogeneic immature DC prevented 


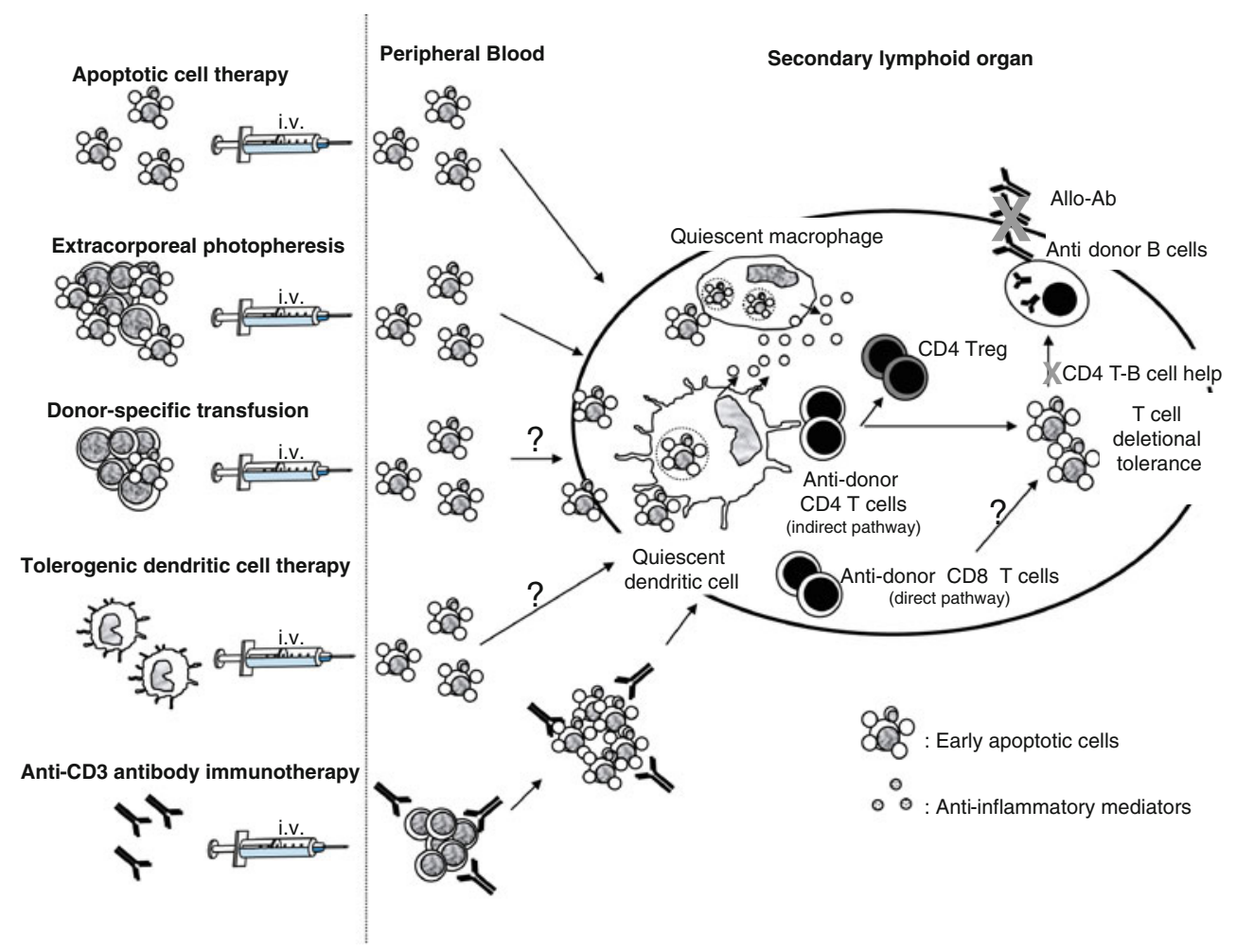

Fig. 2 Summary of the role of apoptotic cells in different immunosuppressive therapies. Apoptotic cell therapy, ECP, DST, tolerogenic $\mathrm{DC}$ therapies and anti-CD3 $\mathrm{Ab}$ immunotherapy likely modulate $\mathrm{Ag}$-specific immune responses and inflammation in transplantation by a common mechanism: in vivo generation of apoptotic cells. Therapeutically-administered (i.v.) or -induced apoptotic cells deliver potent immunosuppressive signals plus the entire repertoire of donor $\mathrm{Ag}$ (the latter in apoptotic cell therapy, DST and tolerogenic DC

development of alloAb following allo-immunization [127], intranasal administration of apoptotic DC in mice suppressed LPS-induced lung inflammation, inhibited host's DC maturation, and inducted Ag-specific CD4 Treg [128], and i.v. infusion of chemically-fixed immature DC prolonged significantly survival of cardiac allografts in mice [129]. Together, these findings strongly suggest that the exogenous DC do not have to be alive to down-regulate the anti-donor response in vivo. Interestingly, in mouse allospecific TCR transgenic models, donor-derived tolerogenic DC injected i.v. in prospective graft recipients did not interact directly with donor-reactive CD4 or CD8 T cells in vivo [130]. Instead, the injected DC were short-lived, internalized as apoptotic cells by recipient's quiescent CD11c ${ }^{\text {hi }}$ DC in the spleen, which presented the donor allopeptides in the context of recipient's MHC molecules to indirect pathway $\mathrm{T}$ cells. This phenomenon led to donorspecific $\mathrm{T}$ cell deletion and increased percentage of donorreactive $\mathrm{T}$ cells expressing the Treg marker FoxP3. These findings strongly suggest that systemic administration of therapies) to quiescent APC of secondary lymphoid organs. Presentation of donor $\mathrm{Ag}$ by these quiescent APC induces defective activation of indirect pathway CD4 T cells followed by $\mathrm{T}$ cell deletion and generation of Treg. As a consequence of the regulatory effects of apoptotic cells on donor-reactive T lymphocytes, allo-specific B cells do not receive adequate help from indirect pathway CD4 T cells and therefore, are unable to differentiate into the plasma cells that secrete alloAb

tolerogenic DC and DST could function indirectly as apoptotic cell-based therapies, by delivering donor $\mathrm{Ag}$ in combination with potent regulatory signals to those recipient's APC that phagocyte the injected cells as soon as they become apoptotic in vivo.

Administration of $\mathrm{CD} 3$-specific monoclonal $\mathrm{Ab}$ results in rapid depletion of $\mathrm{T}$ cells, generation of CD4 Treg, and induction of long-term immune tolerance. Although therapy with anti-CD3 monoclonal $\mathrm{Ab}$ has been employed to treat autoimmune disorders and transplant rejection, its mechanism of action in vivo has been unveiled recently. In a mouse model of experimental autoimmune encephalomyelitis, Perruche et al. [131] have shown that apoptotic T cells induced by the CD3 Ab are internalized by macrophages and immature DC in secondary lymphoid organs. In response to the apoptotic cell interaction, these APC upregulated secretion of TGF- $\beta$, which induced CD4 FoxP3 Treg that together with the $\mathrm{T}$ cell depletion promoted immune tolerance. In fact, in vivo depletion of macrophages and immature DC by administration of clodronate 
liposomes abrogated the beneficial effects of CD3 Ab on prevention and treatment of the autoimmune disease, linking the effect of CD3 Ab to the potent immunoregulatory effect of the therapeutically generated apoptotic cells on phagocytic APC [131].

\section{Concluding remarks}

Since the initial observation that apoptotic cells exert potent regulatory effects on phagocytes of the immune system, in particular APC, numerous laboratories have employed apoptotic cell-based therapies to promote donorspecific immunosuppression in transplantation. Most of the work has being focused in: (1) unveiling the molecular mechanisms behind the immunosuppressive effect; (2) developing practical methods for generation of pro-tolerogenic and clinical-grade apoptotic cells; (3) augmenting their regulatory capacity, by modifying the apoptotic cells or by using them in combination with suboptimal pharmacologic immunosuppression; and (4) finding the optimal route for their delivery.

We have learnt that the use of non-stressed leukocytes undergoing apoptosis, administered i.v., in doses that do not saturate the physiologic mechanisms of apoptotic cell clearance are critical factors to be considered to downregulate inflammatory and immune responses with apoptotic cells. We have also started to connect the dots and realize that other (living) cell-based therapies previously used, currently employed, or under development in transplantation may function simply through generation of apoptotic cells in the graft recipients. However, as in any other scientific field, novel findings lead to new questions. In this regard, it would be interesting to know: what is the probability of triggering autoimmunity or causing allosensitization in transplant recipients following single or repetitive administration of apoptotic cells? How could apoptotic cells be preserved or their immunosuppressive effects enhanced for therapeutic applications? Could the immunoregulatory effect of apoptotic cells be mimicked by administering artificial liposomes bearing ACAMP on their surface? Since previous studies have been conducted in unprimed animals, what is the immunosuppressive potential of apoptotic cell therapies in recipients with high numbers of allo-reactive memory $T$ cells? What is the therapeutic potential of apoptotic cell therapies in nonhuman primate models of transplantation, a transitional model that should be tested before embarking in clinical trials? Some of the questions are currently being investigated. Only time and more experiments will tell us whether the peculiar biological properties of apoptotic cells could be employed more efficiently for treatment of transplant rejection or autoimmune disorders.
Acknowledgments Supported by grants from the National Institutes of Health: R01 HL077545 (A.E.M.) and R01 CA100893 and R01 AI077511 (A.T.L.).

Conflict of interest statement The authors declare they have no conflict of interest.

Open Access This article is distributed under the terms of the Creative Commons Attribution Noncommercial License which permits any noncommercial use, distribution, and reproduction in any medium, provided the original author(s) and source are credited.

\section{References}

1. Voll RE, Herrmann M, Roth EA, Stach J, Kalden R (1997) Immunosuppressive effects of apoptotic cells. Nature 390:350 351

2. Cvetanovic M, Mitchell JE, Patel V, Avner BS, Su Y, van der Saag PT, Witte PL, Fiore S, Levine JS, Ucker DS (2006) Specific recognition of apoptotic cells reveals a ubiquitous and unconventional innate immunity. J Biol Chem 281:2005520067

3. Gallucci S, Lolkema M, Matzinger P (1999) Natural adjuvants: endogenous activators of dendritic cells. Nat Medicine 5:1249 1255

4. Sauter B, Albert M, Francisco L, Larsson M, Somersan S, Bhardwaj N (2000) Consequences of cell death: exposure to necrotic tumor cells, but not primary tissue cells or apoptotic cells, induces the maturation of immunostimulatory dendritic cells. J Exp Med 191:423-433

5. Urban BC, Willcox N, Roberts DJ (2001) A role for CD36 in the regulation of dendritic cell function. Proc Natl Acad Sci (USA) 98:8750-8755

6. Stuart LM, Lucas M, Simpson C, Lamb J, Savill J, Lacy-Hulbert A (2002) Inhibitory effects of apoptotic cell ingestion upon endotoxin-driven myeloid dendritic cell maturation. J Immunol 168:1627-1635

7. Verbovetski I, Bychkov H, Trahtemberg U, Shapira I, Hareuveni M, Ben-Tal O, Kutikov I, Gill O, Mevorach D (2002) Opsonization of apoptotic cells by autologous iC $3 \mathrm{~b}$ facilitates clearance by immature dendritic cells, down-regulates DR and CD86, and up-regulates CC chemokine receptor 7. J Exp Med 196:15531561

8. Takahashi M, Kobayashi Y (2003) Cytokine production in association with phagocytosis of apoptotic cells by immature dendritic cells. Cell Immunol 226:105-115

9. Albert ML, Sauter B, Bhardwaj N (1998) Dendritic cells acquire antigen from apoptotic cells and induce class I-restricted CTLs. Nature 392:86-89

10. Johansson U, Walther-Jallow L, Smed-Sorensen A, Spetz A-L (2007) Triggering of dendritic cell responses after exposure to activated, but not resting, apoptotic PBMCs. J Immunol 179:1711-1720

11. Gurung P, Kucaba TA, Ferguson TA, Griffith TS (2009) Activation-induced CD154 expression abrogates tolerance induced by apoptotic cells. J Immunol 183:6114-6123

12. Albert M (2004) Death-defying immunity: do apoptotic cells influence antigen processing and presentation? Nat Rev Immunol 4:223-231

13. Patel VA, Longacre A, Hsiao K, Fan H, Meng F, Mitchell JE, Rauch J, Ucker DS, Levine JS (2006) Apoptotic cells, at all stages of the death process, trigger characteristic signaling events that are divergent from and dominant over those triggered 
by necrotic cells. Implications for the delayed clearance model of autoimmunity. J Biol Chem 281:4663-4670

14. Morelli AE, Larregina AT, Shufesky WJ, Zahorchack A, Logar A, Papworth GD, Wang Z, Watkins SC, Falo LD Jr, Thomson AW (2003) Internalization of circulating apoptotic cells by splenic marginal zone dendritic cells: dependence on complement receptors and effect on cytokine production. Blood 101:611-620

15. Williams CA, Harry RA, McLeod JD (2007) Apoptotic cells induce dendritic cell-mediated suppression via interferon- $\gamma$ induced IDO. Immunology 124:89-101

16. Ren G, Su J, Zhao X, Zhang L, Zhang J, Roberts AI, Zhang H, Das G, Shi Y (2008) Apoptotic cells induce immunosuppression through dendritic cells: critical roles of IFN- $\gamma$ and nitric oxide. J Immunol 181:3277-3284

17. Stark MA, Huo Y, Burcin TL, Morris MA, Olson TS, Ley K (2005) Phagocytosis of apoptotic neutrophils regulates granulopoiesis via IL-23 and IL-17. Immunity 22:285-294

18. Wang Z, Shufesky WJ, Montecalvo A, Divito SJ, Larregina AT, Morelli AE (2009) In situ-targeting of dendritic cells with donor-derived apoptotic cells restrains indirect allorecognition and ameliorates allograft vasculopathy. PLoS ONE 4(3):e4940

19. Fadok VA, Bratton DL, Konowal A, Freed PW, Westcott JY, Henson PM (1998) Macrophages that have ingested apoptotic cells in vitro inhibit proinflammatory cytokine production through autocrine/paracrine mechanisms involving TGF-beta, PGE2, and PAF. J Clin Invest 101:890-898

20. Huynh M-LN, Fadok VA, Henson PM (2002) Phosphatidylserine-dependent ingestion of apoptotic cells promotes TGF- $\beta 1$ secretion and the resolution of inflammation. J Clin Invest 109:41-50

21. Kim S, Elkon KB, Ma X (2004) Transcriptional suppression of interleukin-12 gene expression following phagocytosis of apoptotic cells. Immunity 21:643-653

22. Morimoto K, Amano H, Sonoda F, Baba M, Senba M, Yoshimime H, Yamamoto H, Ii T, Oishi K, Nagatake T (2001) Alveolar macrophages that phagocytose apoptotic neutrophils produce hepatocyte growth factor during bacterial pneumonia in mice. Am J Respir Cell Mol Biol 24:608-615

23. Inaba K, Turlev S, Yamaide F, Iyoda T, Mahnke K, Inaba M, Pack M, Subklewe M, Sauter B, Sheff D, Albert M, Bhardwaj N, Mellman I, Steinman RM (1998) Efficient presentation of phagocytosed cellular fragments on the major histocompatibility complex class II products of dendritic cells. J Exp Med 11:2163-2173

24. Albert ML, Pearce SFA, Francisco LM, Sauter B, Roy P, Silverstein RL, Bhardwaj N (1998) Immature dendritic cells phagocytose apoptotic cells via $\alpha \mathrm{v} \beta 5$ and CD36, and crosspresent antigens to cytotoxic $\mathrm{T}$ lymphocytes. J Exp Med 188:1359-1368

25. Iyoda T, Shimoyama S, Liu K, Omatsu Y, Akiyama Y, Maeda Y, Takahara K, Steinman RM, Inaba K (2002) The CD8+ dendritic cell subset selectively endocytoses dying cells in culture and in vivo. J Exp Med 195:1289-1302

26. Ross A, Xu W, Castellano G, Nauta AJ, Garred P, Daha MR, van Kooten C (2004) A pivotal role for innate immunity in the clearance of apoptotic cells. Eur J Immunol 34:921-929

27. Larregina AT, Morelli AE (2006) Interaction between dendritic cells and apoptotic cells. In: Lutz M, Romani N, Steinkasserer A (eds) Handbook of dendritic cells, biology, diseases and therapies, vol 2. Wiley-VCH Verlag GmbH \& Co. KGaA, Weinheim, pp 591-618

28. Ravichandran KS, Lorenz U (2007) Engulfment of apoptotic cells: signals for a good meal. Nat Rev Immunol 7:964-974

29. Erwig L-P, Henson PM (2008) Clearance of apoptotic cells by phagocytes. Cell Death Differ 15:243-250
30. Chen X, Doffek K, Sugg SL, Shilyansky J (2004) Phosphatidylserine regulates the maturation of human dendritic cells. J Immunol 173:2985-2994

31. Scott RS, McMahon EJ, Pop SM, Reap EA, Caricchio R, Cohen PL, Earp HS, Matsushima GK (2001) Phagocytosis and clearance of apoptotic cells is mediated by MER. Nature 411:207211

32. Nagata K, Ohashi K, Nakano T, Arita H, Zong C, Hanafusa H, Mizuno K (1996) Identification of the product of the growth arrest-specific gene 6 as a common ligand for Axl, Sky, and Mer receptor tyrosine kinases. J Biol Chem 271:30022-30027

33. Nakano T, Ishimoto Y, Kishimo J, Umeda M, Inoue K, Nagata K, Ohashi K, Mizumo K, Arita H (1997) Cell adhesion to phosphatidylserine mediated by a product of growth arrestspecific gene 6. J Biol Chem 272:29411-29414

34. Behrens EM, Gadue P, Gong S, Garret S, Stein G, Cohen PL (2003) The mer receptor tyrosine kinase: expression and function suggest a role in innate immunity. Eur J Immunol 33:21602167

35. Sen P, Wallet MA, Yi Z, Huang Y, Henderson M, Mathews CE, Earp HS, Matsushima G, Baldwin AS Jr, Tisch RM (2007) Apoptotic cells induce Mer tyrosine kinase-dependent blockade of NF- $\kappa$ B activation in dendritic cells. Blood 109:653-660

36. Castellano G, Woltman AM, Schlagwein N, Xu W, Schena FP, Daha MR, van Kooten C (2007) Immune modulation of human dendritic cells by complement. Eur J Immunol 37:2803-2811

37. Skoberne M, Somersan S, Almodovar W, Truong T, Petrova K, Henson PM, Bhardwaj N (2006) The apoptotic-cell receptor CR3, but not $\alpha_{\mathrm{v} \beta 5}$, is a regulator of human dendritic-cell immunostimulatory function. Blood 108:947-955

38. Behrens EM, Ning Y, Muvarak N, Zoltick PW, Flake AW, Gallucci S (2008) Apoptotic cell-mediated immunoregulation of dendritic cells does not require $\mathrm{iC} 3 \mathrm{~b}$ opsonization. J Immunol 181:3018-3026

39. Gao Y, Herndon JM, Zhang H, Griffith TS, Ferguson TA (1998) Antiinflammatory effects of CD95 ligand (FasL)-induced apoptosis. J Exp Med 188:887-896

40. Chen W, Frank ME, Jin W, Wah SM (2001) TGF-beta released by apoptotic $\mathrm{T}$ cells contributes to an immunosuppressive milieu. Immunity 14:715-725

41. Krispin A, Bledi Y, Atallah M, Trahtemberg U, Verbovetski I, Nahari E, Zelig O, Linial M, Mevorach D (2006) Apoptotic cell thrombospondin-1 and heparin-binding domain led to dendriticcell phagocytic and tolerizing states. Blood 108:3580-3589

42. Ariel A, Fredman G, Sun Y-P, Kantarci A, Van Dyke TE, Luster $\mathrm{AD}$, Serhan CN (2006) Apoptotic neutrophils and $\mathrm{T}$ cells sequester chemokines during immune response resolution through modulation of CCR5 expression. Nat Immunol 7:12091216

43. Steinman RM, Nussenzweig MC (2002) Avoiding horror autotoxicus: the importance of dendritic cells in peripheral $\mathrm{T}$ cell tolerance. Proc Natl Acad Sci (USA) 99:351-358

44. Steinman RM, Hawiger D, Nussenzweig MC (2003) Tolerogenic dendritic cells. Annu Rev Immunol 21:685-711

45. Adler AJ, Marsh DW, Yochum GS, Guzzo JL, Nigam A, Nelson WG, Pardoll DM (1998) CD4+ T cell tolerance to parenchymal self-antigens requires presentation by bone marrow-derived antigen-presenting cells. J Exp Med 187:1555-1564

46. Kurts C, Kosaka H, Carbone FR, Miller JF, Heath WR (1997) Class I-restricted cross-presentation of exogenous self-antigens leads to deletion of autoreactive CD8(+) T cells. J Exp Med 186:239-245

47. Hawiger D, Inaba K, Dorsett Y, Guo M, Mahnke K, Rivera M, Ravetch JV, Steinman RM, Nussenzweig MC (2001) Dendritic cells induce peripheral $\mathrm{T}$ cell unresponsiveness under steady state conditions in vivo. J Exp Med 194:769-779 
48. Bonifaz L, Bonnyay D, Mahnke K, Rivera M, Nussenzweig MC, Steinman RM (2002) Efficient targeting of protein antigen to the dendritic cell receptor DEC-205 in the steady state leads to antigen presentation on major histocompatibility complex class I products and peripheral CD8+ T cell tolerance. J Exp Med 196:1627-1638

49. Mishima Y (1966) Melanosomes in phagocytic vacuoles in Langerhans cells. Electron microscopy of keratin-stripped human epidermis. J Cell Biol 30:417-423

50. Huang F-P, Platt N, Wykes M, Major JR, Powell TJ, Jenkins CD, MacPherson GG (2000) A discrete subpopulation of dendritic cells transports apoptotic intestinal epithelial cells to T cell areas of mesenteric lymph nodes. J Exp Med 191:435-443

51. Scheinecker C, McHugh R, Shevach EM, Germain RN (2002) Constitutive presentation of a natural tissue autoantigen exclusively by dendritic cells in the draining lymph node. J Exp Med 196:1079-1090

52. Parr MB, Kepple L, Parr EL (1991) Langerhans cells phagocytose vaginal epithelial cells undergoing apoptosis during the murine estrous cycle. Biol Reprod 45:252-260

53. Ip WK, Lau Y-L (2004) Distinct maturation of, but not migration between, human monocyte-derived dendritic cells upon ingestion of apoptotic cells of early or late phases. J Immunol 173:189-196

54. Dalgaard J, Beckstrom KJ, Jahnsen FL, Brichmann JE (2005) Differential capacity for phagocytosis of apoptotic and necrotic leukemia cells by human peripheral blood dendritic cell subsets. J Leukoc Biol 77:689-698

55. Liu K, Iyoda T, Saternus M, Kimura Y, Inaba K, Steinman RM (2002) Immune tolerance after delivery of dying cells to dendritic cells in situ. J Exp Med 196:1091-1097

56. Ferguson TA, Herndon J, Elzey B, Griffith TS, Schoenberger S, Green DR (2002) Uptake of apoptotic antigen-coupled cells by lymphoid dendritic cells and cross-priming of CD8(+) T cells produce active immune unresponsiveness. J Immunol 168:55895595

57. Wang Z, Larregina AT, Shufesky WJ, Perone MJ, Montecalvo A, Zahorchack AF, Thomson AW, Morelli AE (2006) Use of the inhibitory effect of apoptotic cells on dendritic cells for graft survival via $\mathrm{T}$-cell deletion and regulatory $\mathrm{T}$ cells. Am $\mathrm{J}$ Transplant 6:1297-1311

58. Luckashenak N, Schroeder S, Endt K, Schmidt D, Mahnke K, Bachmann MF, Marconi P, Deeg CA, Brocker T (2008) Constitutive crosspresentation of tissue antigens by dendritic cells controls CD8 + T cell tolerance in vivo. Immunity 28:521-532

59. Gray M, Miles K, Salter D, Gray D, Savill J (2007) Apoptotic cells protect mice from autoimmune inflammation by induction of regulatory B cells. Proc Natl Acad Sci (USA) 104:14080-14085

60. Botto M, Dell'Agnola C, Bygrave AE, Thompson EM, Cook HT, Petry F, Loss M, Pandolfi PP, Walport MJ (1998) Homozygous $\mathrm{C} 1 \mathrm{q}$ deficiency causes glomerulonephritis associated with multiple apoptotic bodies. Nat Genet 19:56-59

61. Chen Z, Koralov SB, Kelsoe G (2000) Complement C4 inhibits systemic autoimmunity through a mechanism independent of complement receptors CR1 and CR2. J Exp Med 192:13391352

62. Bickerstaff MC, Botto M, Hutchinson WL, Herbert J, Tennent GA, Bybee A, Mitchell DA, Cook HT, Butler PJ, Walport MJ, Pepys MB (1999) Serum amyloid P component controls chromatin degradation and prevents antinuclear autoimmunity. Nat Med 5:694-697

63. Ehrenstein MR, Cook HT, Neuberger MS (2000) Deficiency in serum immunoglobulin (Ig)M predisposes to development of IgG autoantibodies. J Exp Med 191:1253-1258

64. Cohen PL, Caricchio R, Abraham V, Camenisch TD, Jennette JC, Roubey RA, Earp HS, Matsushima G, Reap EA (2002)
Delayed apoptotic cell clearance and lupus-like autoimmunity in mice lacking the c-mer membrane tyrosine kinase. J Exp Med 196:135-140

65. Wallet MA, Sen P, Flores RR, Wang Y, Yi Z, Huang Y, Mathews CE, Earp HS, Matsushima G, Wang B, Tisch R (2008) MerTK is required for apoptotic cell-induced T cell tolerance. $\mathrm{J}$ Exp Med 205:219-232

66. Hanayama R, Tanaka M, Miyasaka K, Aozasa K, Koike M, Uchiyama Y, Nagata S (2004) Autoimmune disease and impaired uptake of apoptotic cells in MFG-E8-deficient mice. Science 304:1147-1150

67. Wermeling F, Chen Y, Pikkarainen T, Scheynius A, Winqvist O, Izui S, Ravetch JV, Tryggvason K, Karlsson MC (2007) Class A scavenger receptors regulate tolerance against apoptotic cells, and autoantibodies against these receptors are predictive of systemic lupus. J Exp Med 204:2259-2265

68. Nagata S (2007) Autoimmune diseases caused by defects in clearing dead cells and nuclei expelled from erythroid precursors. Immunol Rev 200:237-250

69. Truedsson L, Bengtsson AA, Sturfelt G (2007) Complement deficiencies and systemic lupus erythematosus. Autoimmunity 40:560-566

70. Taylor PR, Carugati A, Fadok V, Cook HT, Andrews M, Carroll MC, Savill JS, Henson PM, Botto M, Walport MJ (2000) A hierarchical role for classical pathway complement proteins in the clearance of apoptotic cells in vivo. J Exp Med 192:359-366

71. Baumann I, Kolowos W, Voll RE, Manger B, Gaipl U, Neuhuber WL, Kirchner T, Kalden JR, Herrmann M (2002) Impaired uptake of apoptotic cells into tingible body macrophages in germinal centers of patients with systemic lupus erythematosus. Arth Rheum 46:191-201

72. Shoshan Y, Shapira I, Toubi E, Frolkis I, Yaron M, Mevorach D (2001) Accelerated Fas-mediated apoptosis of monocytes and maturing macrophages from patients with systemic lupus erythematosus: relevance to in vitro impairment of interaction with iC3b-opsonized apoptotic cells. J Immunol 167:5963-5969

73. Steinman RM, Turley S, Mellman I, Inaba K (2000) The induction of tolerance by dendritic cells that have captured apoptotic cells. J Exp Med 191:411-416

74. Morelli AE (2006) The immune regulatory effect of apoptotic cells and exosomes on dendritic cells: its impact on transplantation. Am J Transplant 6:254-261

75. Saas P, Bonnefoy F, Kury-Paulin S, Kleinclauss F, Perruche S (2007) Mediators involved in the immunomodulatory effects of apoptotic cells. Transplantation 84:S31-S34

76. Divito SJ, Morelli AE (2009) Apoptotic cells for therapy of transplant rejection. In: Krysko DV, Vandenabeele P (eds) Phagocytosis of dying cells: from molecular mechanisms to human diseases. Springer Netherlands, pp 319-346

77. Sun E, Gao Y, Chen J, Roberts A, Wang X, Chen Z, Shi Y (2004) Allograft tolerance induced by donor apoptotic lymphocytes requires phagocytosis in the recipient. Cell Death Differ 11:1258-1264

78. Kleinclauss F, Perruche S, Masson E, de Carvalho Bittencourt M, Biichle S, Remy-Martin J-P, Ferrand C, Martin M, Bittard H, Chalopin J-M, Seilles E, Tiberghien P, Saas P (2006) Intravenous apoptotic spleen cell infusion induces a TGF- $\beta$-dependent regulatory T-cell expansion. Cell Death Differ 13:41-52

79. Qiu CH, Miyase Y, Kaise H, Kitamura H, Ohara O, Tanaka M (2009) Novel subset of $C D 8 \alpha+$ dendritic cells localized in the marginal zone is responsible for tolerance to cell-associated antigens. J Immunol 182:4127-4136

80. Xu DL, Liu Y, Tan J-M, Li B, Zhong C-P, Zhang XH, Wu C-Q, Tang X-D (2004) Marked prolongation of murine cardiac allograft survival using recipient immature dendritic cells loaded with donor-derived apoptotic cells. Scand J Immunol 59:536-544 
81. Miyake Y, Asano K, Kaise H, Uemura M, Nakayama M, Tanaka M (2007) Critical role of macrophages in the marginal zone in the suppression of immune responses to apoptotic cell-associated antigens. J Clin Invest 117:2268-2278

82. Nouri-Shirazi M, Guinet E (2002) Direct and indirect crosstolerance of alloreactive $\mathrm{T}$ cells by dendritic cells retained in the immature stage. Transplantation 74:1035-1044

83. De Carvalho Bittencourt M, Perruche S, Contassot E, Fresnay S, Baron MH, Angonin R, Aubin F, Herve P, Tiberghien P, Saas P (2001) Intravenous injection of apoptotic leukocytes enhances bone marrow engraftment across major histocompatibility barriers. Blood 98:224-230

84. Perruche S, Kleinclauss F, de Carvalho Bittencourt M, Paris D, Tiberghien P, Saas P (2004) Intravenous infusion of apoptotic cells simultaneously with allogeneic hematopoietic grafts alters anti-donor humoral immune responses. Am J Transplant 4:1361-1365

85. Ludvigsson J, Samuelsson U, Ernerudh J, Johansson C, Stenhammar L, Berlin G (2001) Photopheresis at onset of type 1 diabetes: a randomised, double blind, placebo controlled trial. Arch Dis Child 85:149-154

86. Perez M, Edelson R, Laroche L, Berger C (1989) Inhibition of antiskin allograft immunity by infusions with syngeneic photoactivated effector lymphocytes. J Invest Dermatol 92:669-676

87. Pepino P, Berger CL, Fuzesi L, Panza A, Pierson RN, Gutierrez C, Marboe CC, Smith CR, Reemtsma K, Rose EA (1989) Primate cardiac allo- and xeno-transplantation: modulation of the immune response with photochemotherapy. Eur Surg Res 21:105-113

88. Barr ML, Meisner BM, Eisen HJ, Roberts RF, Ugolino L, Dall'Amico R, Dorent R, Rogers JG, Radovancevic B, Taylor DO, Jeevanandam V, Marboe CC (1998) Photopheresis for the prevention of rejection in cardiac transplantation. New Eng $\mathbf{J}$ Med 339:1744-1751

89. Costanzo-Nordin MR, Hubbell EA, O'Sullivan EJ, Johnson MR, Mullen GM, Heroux AL, Kao WG, McManus BM, Pifarre R, Robinson JA (1992) Photopheresis versus corticosteroids in the therapy of heart transplant rejection. Preliminary clinical report. Circulation 86((Suppl II)):242-250

90. Costanzo-Nordin MR, Hubbell EA, O'Sullivan EJ, Johnson MR, Mullen GM, Heroux AL, Kao WG, McManus BM, Pifarre R, Robinson JA (1992) Successful treatment of heart transplant rejection with photopheresis. Transplantation 53:808-815

91. Horina JH, Mulleger RR, Horn S, Holzer H, Halwachs G, Kerl H, Wolf P (1995) Photopheresis for renal allograft rejection. Lancet 346:61

92. Bhandari JMJ, Wyburn KR, Misra AK, McKenzie PR, Eris JM (2009) Photopheresis therapy for problematic renal allograft rejection. J Clin Apher 24:161-169

93. Speich BC, Hofbauer GF, Irani S, Eich-Wanger C, Russi EW, Weder W, Boehler A (2008) Extracorporeal photopheresis after lung transplantation: a 10-year single-center experience. Transplantation 86:1625-1627

94. Urbani L, Mazzoni A, Colombatto P, Biancofiore G, Bindi L, Tascini C, Menichetti F, Brunetto M, Filipponi F (2008) Potential applications of extracorporeal photopheresis in liver transplantation. Transplant Proc 40:1175-1178

95. Hivelin M, Siemionow M, Grimbert P, Lantieri L (2009) Extracorporeal photopheresis: from solid organs to face transplantation. Transpl Immunol 21:117-128

96. Greinix HT, Volc-Platzer B, Kalhs P, Fischer G, Rosenmayr A, Keil F, Honigsmann H, Knobler RM (2000) Extracorporeal photochemotherapy in the treatment of severe steroid-refractory acute graft-versus-host disease: a pilot study. Blood 96:24262431
97. Flowers ME, Apperley JF, van Besien K, Elmaagacli A, Grigg A, Reddy V, Bacigalupo A, Kolb HJ, Bouzas L, Michallet M, Prince HM, Knobler R, Parenti D, Gallo J, Greinix HT (2008) A multicenter prospective phase 2 randomized study of extracorporeal photopheresis for treatment of chronic graft-versus-host disease. Blood 112:2667-2674

98. Lim HW, Edelson RL (1995) Photopheresis for the treatment of cutaneous T-cell lymphoma. Hematol Oncol Clin North Am 9:1117-1126

99. Suchin KR, Cassin M, Washko R, Nahass G, Berkson M, Stouch B, Vowels BR, Rook AH (1999) Extracorporeal photochemotherapy does not suppress $\mathrm{T}$ - or B-cell responses to novel or recall antigens. J Am Acad Dermatol 41:980-986

100. Maeda A, Schwarz A, Kernebeck K, Gross N, Aragane Y, Peritt D, Schwarz T (2005) Intravenous infusion of syngeneic apoptotic cells by photopheresis induces antigen-specific regulatory T cells. J Immunol 174:5968-5976

101. Maeda A, Schwarz A, Bullinger A, Morita A, Peritt D, Schwarz $\mathrm{T}$ (2008) Experimental extracorporeal photopheresis inhibits the sensitization and effector phases of contact hypersensitivity via two mechanisms: generation of IL-10 and induction of regulatory T cells. J Immunol 181:5956-5962

102. Craciun LI, Stordeur P, Schandene L, Duvillier H, Bron D, Lambermont M, Goldman M, Dupont E (2002) Increased production of interlukin-10 and interleukin-1 receptor antagonist after extracorporeal photochemotherapy in chronic graft-versushost disease. Transplantation 74:995-1000

103. Rizzo R, Melchiorri L, Tazzari PL, Tassi C, Soli M, Lunghi M, Belloni M, Conte R, Baricordi OR (2005) Increased production of soluble HLA-G molecules in stimulated peripheral blood mononuclear cells following extracorporeal photopheresis: is it a mechanisms involved in the therapeutic effect of the procedure? J Clin Apher 20:222-224

104. Lamioni A, Parisi F, Isacchi G, Giordia E, Di Cesare S, Landolfo A, Cenci F, Bottazzo GF, Carsetti R (2005) The immunological effects of extracorporeal photopheresis unraveled: Induction of tolerogenic dendritic cells in vitro and regulatory $\mathrm{T}$ cell in vivo. Transplantation 79:846-850

105. Rao V, Saunes M, Jorstad S, Moen T (2008) In vitro experiments demonstrate that monocytes and dendritic cells are rendered apoptotic by extracorporeal photochemotherapy, but exhibit unaffected surviving and maturing capacity after 30 Gy gamma irradiation. Scand J Immunol 68:645-651

106. Stadler K, Frey B, Munoz LE, Finzel S, Rech J, Fietkau R, Herrmann M, Hueber A, Gaipl US (2009) Photopheresis with UV-A light and 8-methoxypsoralen leads to cell death and to release of blebs with anti-inflammatory phenotype in activated and nonactivated lymphocytes. Biochem Biophys Res Commun 386:71-76

107. Holtick U, Marshall SR, Wang XN, Hilkens CM, Dickinson AM (2008) Impact of psoralen/UVA-treatment on survival, activation, and immunostimulatory capacity of monocyte-derived dendritic cells. Transplantation 83:757-766

108. Gerner M, Holig K, Wehner R, Zhao S, Schakel K, Bachmann MP, Rieber EP, Bornhauser M, Schmitz M (2009) Extracorporeal photopheresis efficiently impairs the proinflammatory capacity of human 6-sulfo LacNac dendritic cells. Transplantation 87:1134-1139

109. Di Renzo M, Sbano P, De Aloe G, Pasqui AL, Rubegni P, Ghezzi A, Auteri A, Fimiani M (2008) Extracorporeal photopheresis affects co-stimulatory molecule expression and interleukin-10 production by dendritic cells in graft-versus-host disease patients. Clin Exp Immunol 151:407-413

110. George JF, Gooden CW, Guo WH, Kirklin JK (2008) Role for $\mathrm{CD} 4^{+} \mathrm{CD} 25^{+} \mathrm{T}$ cells in inhibition of graft rejection by extracorporeal photopheresis. J Heart Lung Transplant 27:616-622 
111. Gatza E, Rogers CE, Clouthier SG, Lowler KP, Tawara I, Liu C, Reddy P, Ferrara JLM (2008) Extracorporeal photopheresis reverses experimental graft-versus-host disease through regulatory T cells. Blood 112:1515-1521

112. Meloni F, Cascina A, Miserere S, Perotti C, Vitulo P, Fietta AM (2007) Peripheral CD4(+)CD25(+) TREG cell counts and the response to extracorporeal photopheresis in lung transplant recipients. Transplant Proc 39:213-217

113. Lamioni A, Carsetti R, Legato A, Landolfo A, Isacchi G, Emma F, Bottazzo GF, Dello Strologo L (2007) Induction of regulatory $\mathrm{T}$ cells after prophylactic treatment with photopheresis in renal transplant recipients. Transplantation 83:1393-1396

114. Di Biaso I, Di Maio L, Bugarin C, Gaipa G, Dander E, Balduzzi A, Parma M, D’Amico G, Perseghin P, Biondi A, Biagi E (2009) Regulatory $\mathrm{T}$ cells and extracorporeal photochemotherapy: correlation with clinical response and decreased frequency of proinflammatory $\mathrm{T}$ cells. Transplantation 87:1422-1425

115. Schmitt S, Johnson TS, Karakhanova S, Naher H, Mahnke K, Enk AH (2009) Extracorporeal photopheresis augments function of CD4+ CD25+ FoxP3+ regulatory $\mathrm{T}$ cells by triggering adenosine production. Transplantation 15:411-416

116. Newton WT, Anderson CB (1973) Planned preimmunization of renal allograft recipients. Surgery 74:430-436

117. Opelz G, Serger DPS, Mickey MR, Terasaki PI (1973) Effect of blood transfusion on subsequent kidney transplants. Transplant Proc 5:253-259

118. Salvatierra O, Vicenti F, Amed W (1980) Deliberate donorspecific blood transfusion prior to living related renal transplantation. A new approach. Ann Surg 192:543-552

119. Madsen JC, Superina RA, Wood KJ, Morris PJ (1988) Immunological unresponsiveness induced by recipient cells transfected with donor MHC genes. Nature 332:161-164

120. Wood ML, Gottschalk R, Monaco AP (1984) Comparison of immune responsiveness in mice after single or multiple donorspecific transfusions. J Immunol 132:651-655

121. Persijn CG, Cohen B, Lansbergen Q, van Rood JJ (1979) Retrospective and prospective studies on the effect of blood transfusions in renal transplantation in The Netherlands. Transplantation 28:396-401

122. Brennan DC, Mohanakumar T, Flye MW (1995) Donor-specific transfusion and donor bone marrow infusion in renal transplantation tolerance: a review of efficacy and mechanisms. Am J Kidney Dis 26:701-715

123. Niimi M, Roelen DL, Witzke O, van Rood JJ, Claas FHJ, Wood KJ (2000) The importance of $\mathrm{H} 2$ haplotype sharing in the induction of specific unresponsiveness by pretransplant blood transfusions. Transplantation 69:411-417

124. Quezada SA, Fuller B, Jarvinen LZ, Gonzalez M, Blazar BR, Rudensky AY, Strom TB, Noelle RJ (2003) Mechanisms of donor-specific transfusion tolerance: preemptive induction of clonal T-cell exhaustion via indirect presentation. Blood 102:1920-1926

125. Kishimoto K, Yuan X, Auchincloss H, Sharpe AH, Mandelbrot DA, Sayegh MH (2004) Mechanisms of action of donor-specific transfusion in inducing tolerance: role of donor MHC molecules, donor co-stimulatory molecules, and indirect antigen presentation. J Am Soc Nephrol 15:2423-2428

126. Morelli AE, Thomson AW (2007) Tolerogenic dendritic cells and the quest for transplant tolerance. Nat Rev Immunol 7: $610-621$

127. Xia C-Q, Kao K-J (2005) Induction of immune tolerance across major histocompatibility complex barrier by transfusion of ultraviolet B-irradiated immature dendritic cells. Transfusion 45:181-188

128. Kushwah R, Oliver JR, Zhang J, Siminovitch KA, Hu J (2009) Apoptotic dendritic cells induce tolerance in mice through suppression of dendritic cell maturation and induction of antigen-specific regulatory T cells. J Immunol 183:7104-7118

129. Oh BC, Lee HM, Lim DP, Cho JJ, Lee G, Lee DS, Lee JR (2006) Effect of immature dendritic cell injection before heterotopic cardiac allograft. Transplant Proc 38:3189-3192

130. Divito SJ, Shufesky WJ, Wang Z, Montecalvo A, Morelli AE (2008) Donor-derived tolerogenic dendritic cells are reprocessed into and presented as alloAg by recipient dendritic cells to down-regulate anti-donor $\mathrm{T}$ cells and prolong allograft survival. Am J Transplant 8(Suppl 2):226

131. Perruche S, Zhang P, Liu Y, Saas P, Bluestone JA, Chen W (2007) CD3-specific antibody-induced immune tolerance involves transforming growth factor- $\beta$ from phagocytes digesting apoptotic T cells. Nat Immunol 14:528-535 